DOI 10.31558/2519-2949.2020.3.5

УДК 326:327.8:343.8:343.9

ORCID ID: https://orcid.org/0000-0002-2822-2268

Ягунов Д. В., Донецький національний університет імені Василя Стуса

\title{
ПУНІТИВНЕ МІСТО ПОСТМОДЕРНУ: ДО ПИТАННЯ ПРО ДИСПЕРСІЮ СОЦАЛЬНОГО КОНТРОЛЮ У ХХІ СТОЛІТТІ
}

\begin{abstract}
Стаття присвячена проблемі сутності, форм, методів та меж соціального контролю у суспільстві Постмодерну. Стаття містить аналіз поглядів найбільш відомих вчених, які заклали підвалини сучасного розуміння соціального контролю, та авторські пропозииї щцодо застосування таких поглядів у суспільстві ХХІ століття. Головню тезою цього дослідження є те, що сучасний соиіальний контроль є більш проникливим, тонким та всеосяжним (передусім в силу своєї більшої технологічності), а відтак існує реальна небезпека втрати свободи у суспільстві Постмодерну. У статті робиться наголос на важливості для політичної науки ХХІ століття прачь франиузького філософа Мішеля Фуко та американського сочіолога Стенлі Коена щеоо сутності соиіального контролю на прикладі концепиї карального (пунітивного) міста, яке служить моделлю сучасного суспільства технологічного соціального контролю. У статті міститься аналіз трансформації моделей соціального контролю з відповідними характеристиками кожної моделі. Стаття аналізує питання застосування у XXI столітті категорій, запроваджених Мімелем Фуко («ранг», «іспит», «дисципліна») і фокусує увагу на актуальності таких категорій. У статті надаються практичні приклади «посягання на свободу» (як-то камери відеоспостереження, інформаиійні бази даних, розиирення типології та класифікації девіантів) та поширення більш проникливого сочіального контролю у сфері кримінальної юстиції. Окрема увага приділена прикладам застосування концепиії net widening у національних системах кримінальної юстииії. Окрема увага приділясться «кризі реабілітаційного ідеалу», щу настала після публікації у 1971 році праџі американського соиіолога Роберта Мартінсона. Стаття містить висновок, щчо свобода - це влада. Влада не як негативна категорія, пов'язана з примусом, а як категорія позитивна, пов 'язана з необмеженою реалізачією своєї волі у суспільстві таких же вільних людей, без шкоди для себе та оточуючих. Тому з иієї позииї класичний формальний підхід до сочіального контролю як до природнього консенсусу, який з'явився невідомо як і невідомо звідки, має сприйматися критично. Сучасне суспільство - ие суспільство тонкої, прозорої, проте водночас жорсткої влади, яка не толерує владу дійсно вільних людей. Головним висновком иььго дослідження буде саме загострення проблематики добровільної відмови від свободи на користь «безпеки», або, краще сказати, поєднання «безпеки» з «комфортом» відповідно до вимог споживачького глобалізованого суспільства.

Ключові слова: глобалізачія, національна держава, пенітенціарна система, пенітенціарна установа, в'язниия, сочіальний контроль, межі соиіального контролю, цілі кримінального покарання, тотальні інституиії, «каральне місто».
\end{abstract}

\section{Постановка проблеми у загальному вигляді та ї̈ зв'язок із важливими науковими чи практичними завданнями. \\ Проблематика соціального контролю $є$ перманентно актуальною для політичної науки. 3 одного} боку, сутність, форми, прояви, методи, суб'єкти та об'єкти соціального контролю були описані упродовж другої половини XX століття багатьма авторами, причому описані настільки глибоко та фундаментально, що додати щось до класичних праць, наприклад, Мішеля Фуко або Стенлі Коена $€$ більш ніж важким академічним завданням. 3 іншого боку, ці фундаментальні праці були написані у 1970-х роках, а тому розвиток нового технологічного суспільства Постмодерну характеризується більш сучасними й більш гнучкими й прозорими формами соціального контролю, у зв'язку з чим виникає питання щодо форм та меж сучасного соціального контролю, а також сутності категорії свободи у суспільстві Постмодерну. Відтак саме початок XXI століття додав до цієї проблематики помітної гостроти, яка визначає актуальність досліджень у цьому напрямку. 
Формулювання мети статті (постановка завдання).

У цій статті ми ставимо за мету проаналізувати проблематику сутності, форм, методів, обсягів та меж соціального контролю крізь призму наукових поглядів авторів, які заснували наукові концепції, пов’язані з виникненням та дисперсією соціального контролю у капіталістичному суспільстві (Георг Руше, Отто Кіркхеймер, Мішель Фуко, Стенлі Коен, Зігмунт Бауман). Крім того, до переліку цілей цього дослідження входить надання відповідних пропозицій щодо застосування поглядів зазначених авторів у глобалізованому суспільстві, враховуючи події XXI століття, які можуть вважатися знаковими для політичної науки.

Аналіз останніх досліджень і публікацій, в яких започатковано розв'язання даної проблеми і на які спирасться автор.

Це дослідження базується на науковій праці американського соціолога Стенлі Коена «Візії соціального контролю. Злочин, покарання та класифікація» та окремих критичних працях сучасних західних вчених щодо застосування думок С. Коена щодо соціального контролю.

У свою чергу праці Стенлі Коена багато у чому засновані на критичному аналізі праць видатних німецьких вчених Георга Руше та Отто Кіркхеймера («Покарання та соціальна структура») стосовно того, що конкретні види покарань, система покарань та спрямованість системи соціального контролю в цілому обумовлена виключно конкретною моделлю економічного виробництва, за умови якої інші види покарань та інших заходів соціального контролю щодо девіантів стають економічно невигідними. Так, наприклад, внаслідок переходу країн Свропи від Середньовіччя до капіталізму саме економічна невигідність тілесних покарань обумовила їх зникнення.

В свою чергу, такий підхід знайшов своє подальше відображення у поглядах італійських вчених Даріо Мелоссі та Массімо Паваріні («В’язниця і фабрика»).

Так само проблематика цієї статті базується на фундаментальній праці французького філософа Мішеля Фуко «Наглядати й карати», яку Стенлі Коен яскраво та обгрунтовано визначив як «найбільш марксистська з усіх праць Фуко» [1]. Віддаючи належне значенню цієї праці Мішеля Фуко, варто процитувати слова Стенлі Коена: «Говорити сьогодні про покарання та контроль без Фуко - це так само, як говорити про підсвідоме без Фрейда» [2, с. 7]. Адже саме Фуко - це найбільш амбітний та загадковий представник дисциплінарної моделі» [2, с. 24].

У цьому контексті також не можна не згадати польського соціолого Зігмунта Баумана 3 його думками щодо дисперсії соціального контролю та створення закритих просторів свободи - «гетто свободи» або «просторів безпеки» [3]. Крім того, це дослідження базується на наукових поглядах німецького вченого Ульріха Бека щодо особливостей соціального контролю в добу глобалізації [4]. До уваги також бралися думки норвезького філософа Ларса Свендсена щодо зміни сутності свободи та тотального масового стеження у сучасних суспільствах [5].

Виділення невирішених раніше частин загальної проблеми, котрим присвячується стаття.

Беручи до уваги, що зазначені вище наукові праці та відповідні висновки не є поширеними у вітчизняній науці, перед нами постає завдання представити науковій спільноті думки та наукові погляди зазначених вище авторів, які, ми переконані, мають знайти своє поширення в українській науці.

Виклад основного матеріалу дослідження з повним обгрунтуванням отриманих результатів.

Загальна риса у поглядах зазначених вище авторів (Кіркхеймер, Руше, Фуко, Мелоссі, Паваріні, Коен, Бауман та інші) полягає у тому, що усі вони пов'язують зміну сутності, форм та меж соціального контролю зі змінами соціально-економічної формації, а головне - виходять далеко за рамки класично-формальних поглядів на інституції соціального контролю, політичну функцію кримінального покарання та інших форм соціального контролю, особливо беручи до уваги, що саме класично-формальний підхід є домінуючим у вітчизняній політичній науці.

Вперше це було грунтовно досліджено Руше i Кіркхеймером в їх фундаментальній праці «Покарання та соціальна структура». Саме Руше і Кіркхеймер сформулювали основоположні тези, які не втратили актуальності в суспільстві Постмодерну, та на яких, власне, базується й наше політичне дослідження.

Так, Мішель Фуко наступним чином надзвичайно слушно визначив значущість праці Руше та Кіркхеймера для цілей дослідження сутності соціального контролю: «Велика праця Руше та Кірхеймера дає кілька найважливіших орієнтирів. Перш за все, треба позбутися ілюзії, ніби кримінально-правова система $є$ головним чином (якщо не виключно) засобом боротьби 3 правопорушеннями і ніби в цій ролі, в залежності від соціальних форм, політичних систем або поглядів, вона буває суворою або м’якою, може бути націлена на спокутування 
або відшкодування. ... У рабовласницькому суспільстві каральні механізми служать створенню додаткової робочої сили - створенню «громадянського» поневолення поряд 3 поневоленням в результаті завоювань або торгівлі. При феодалізмі, в епоху, коли гроші та виробництво тільки починають розвиватися, спостерігається різке зростання числа тілесних покарань - адже для більшості людей тіло є єдиною власністю, наявної в їх розпорядженні. Виправний будинок, примусова праця й тюремні підприємства виникають разом з ринковою економікою. Але система промислового виробництва вимагає вільного ринку робочої сили, і тому в XIX столітті частка примусової праці в механізмах виконання покарань скорочується і він поступається місцем ув'язненню у виправних цілях...» [6, с. 37-38].

Стенлі Коен, у свою чергу, також засновуючи свої наукові погляди на працях Руше, Кіркхеймера та Фуко, надає своє бачення трансформації сутності соціального контролю, що зображується Коеном наступним чином:

1) посилення участі держави у сфері контролю за девіантністю: розвиток централізованого, раціоналізованого і бюрократичного апарату для контролю за злочинністю та покарання злочинців, догляду чи «лікування» інших видів девіантів;

2) зростаюча диференціація та класифікація девіантних та інших цільових груп на окремі типи та категорії, кожна з власним набором наукових знань та відповідних акредитованих «експертів»;

3) збільшення обсягів сегрегації девіантів у «притулках», в'язницях, психіатричних лікарнях, реформаторіях та інших закритих спеціальних установах, де закриті інституції розглядаються як домінуючий інструмент зміни небажаної поведінки та водночас як вигідна форма покарання;

4) зменшення обсягів публічних покарань, які завдають фізичного болю: душа замінює тіло як об'єкт покарання для виправдання самого покарання; виникнення позитивістських теорій про окремого правопорушника, а не про правопорушення [2, с. 13-14].

Основні фази зміни сутності соціального контролю за Коеном наведені у поданій нижче таблиці:

\begin{tabular}{|c|c|c|c|}
\hline & До XIX cm. & 3 початку XIX cm. & 3 середини XX ст. \\
\hline $\begin{array}{l}\text { Втручання } \\
\text { держави }\end{array}$ & $\begin{array}{c}\text { Слабке, незначне, } \\
\text { децентралізоване, } \\
\text { свавільне }\end{array}$ & $\begin{array}{l}\text { Сильне, суттєве, } \\
\text { централізоване, } \\
\text { раціоналізоване }\end{array}$ & $\begin{array}{c}\text { Ideological attack: на фоні } \\
\text { декларацій щодо «minimal state» } \\
\text { має місце інтенсифікація } \\
\text { інтервенції та посилення } \\
\text { соціального контролю } \\
\end{array}$ \\
\hline $\begin{array}{l}\text { Об'єкт } \\
\text { втручання }\end{array}$ & $\begin{array}{c}\text { Зовнішня поведінка } \\
\text { («тіло») }\end{array}$ & $\begin{array}{c}\text { Внутрішній стан } \\
\text { («душа») }\end{array}$ & $\begin{array}{c}\text { Ideological attack: } \\
\text { повернення до «поведінки» } \\
\text { зі збереженням «душі» } \\
\text { як об’єкту втручання }\end{array}$ \\
\hline $\begin{array}{l}\text { Місця } \\
\text { соціального } \\
\text { контролю }\end{array}$ & $\begin{array}{l}\text { Відкриті: громада та } \\
\text { базові інституції }\end{array}$ & $\begin{array}{c}\text { Закриті: сегреговані } \\
\text { інституції: «перемога } \\
\text { ув’язнення» («Велика } \\
\text { інкарцерація») }\end{array}$ & $\begin{array}{c}\text { Ideological attack: на фоні } \\
\text { задекларованих «декарцерації» } \\
\text { та «покарань у громаді» } \\
\text { залишаються старі форми } \\
\text { соціального контролю } \\
\text { з одночасним посиленням нових } \\
\text { форм соціального контролю } \\
\text { у громаді } \\
\end{array}$ \\
\hline $\begin{array}{l}\text { Видимість } \\
\text { соціального } \\
\text { контролю } \\
\end{array}$ & $\begin{array}{l}\text { Відкритий, публічний, } \\
\text { театральний }\end{array}$ & $\begin{array}{c}\text { Кордони } є \text { чіткими, } \\
\text { місця контролю } € \\
\text { невидимими }\end{array}$ & Розмивання кордонів \\
\hline $\begin{array}{l}\text { Гегемонія права } \\
\text { та кримінальної } \\
\text { юстиції }\end{array}$ & $\begin{array}{c}\text { Кримінальна юстиція } \\
\text { не сформована, } \\
\text { кримінальне право } \\
\text { залишається єдиною } \\
\text { формою соціального } \\
\text { контролю }\end{array}$ & $\begin{array}{c}\text { Монополія кримінальної } \\
\text { юстиції з подальшим } \\
\text { заснуванням нових систем } \\
\text { соціального контролю }\end{array}$ & $\begin{array}{c}\text { Ideological attack: } \\
\text { «декриміналізація» } \\
\text { та «відсторонення } \\
\text { від в’язниці» }\end{array}$ \\
\hline
\end{tabular}

Наголошуючи на тезі домінанти економічної складової при зміні різних форм соціального контролю у суспільствах Європи, Фуко і Коен, тим не менше, надають комплексний аналіз цієї проблематики та слушно вказують, що, дійсно, не можна прибирати з порядку денного ідеологічні 
аспекти зміни сутності та форм соціального контролю: «Мета зміни особи [у закритих інституціях] становила форму патріотичного ентузіазму внаслідок звільнення від жорстокої європейської монархічної спадщини та [водночас] була формою відторгнення [огидних] видовищ публічного тілесного покарання. Песимістичні кальвіністські погляди про вроджену розбещеність [людини] були замінені більш оптимістичними поглядами пост-Просвітництва на людей як пластичних істот, які могли бути змінені у [сприятливому] оточенні» [2, с. 20]. Проте водночас треба зробити наголос, що така філантропічна ідея безпосередньо межувала з утопічністю, адже «притулок» був задуманий як «мікрокосм досконалого суспільного порядку, утопічний експеримент, де злочинці й божевільні, відокремлені від дурного впливу, будуть змінені через їх підкорення режиму дисципліни, порядку та детальній регламентації часу» [2, с. 19].

Природньою метою нової модальності соціального контролю, запровадженої у XIX столітті, яка перекочувала до XX століття, було формування нових політичних відносин влади та оточення людини невидимою павутиною нових знань та проектів, де, власне, в центрі уваги опинилася не сама людина, а «небезпека», яку являла або могла являти людина: «Організовується цілий корпус індивідуалізуючого знання, область значення якого - не стільки скоєний злочин (принаймні не він один), скільки потенційна небезпека, прихована в індивіді, яка виявляється у його щоденній поведінці» [6, с. 186].

У XIX столітті виникла потреба у масовій, організованій, сталій та контрольованій дисципліні, однієї зі складових елементів якої $є$ тотальні інституції у самому широкому розумінні цього слова: «Дисципліна іноді вимагає відгородження, специфікації місця, відмінного від всіх інших й замкнутого в самому собі. Відгородженого місця дисциплінарної монотонності. Було велике «ув'язнення» бродяг і жебраків, були й інші, менш помітні, але підступні й дієві» [6, с. 206].

Відтак, з погляду історії соціального контролю, XIX століття - це століття «Великої інкарцерації», коли злочинці були розміщені у в'язницях, психічнохворі - у шпиталях, призовники у казармах, робітники - на фабриках та заводах, діти - у коледжах та школах. Все це становило частину Великого Плану, адже власність має бути захищена, продукція - стандартизована, молодь ізольована для навчання навичкам заощадливості та успіху, злочинці - піддані впливу дисципліні та нагляду за ширмою «виправлення». У новому карцерному суспільстві влада повинна «розтікатися» у найбільш економічно ефективний спосіб та проникати на максимальну глибину через найменші щілини, чому мав сприяти розгалужений дисциплінарний апарат, де в'язниця та усі ії численні додатки (як відкриті, так і приховані) посідали одне з перших місць.

У цьому контексті варто наголосити, що зазначений вище перелік дисциплінарних інституцій не $\epsilon$ вичерпним, і ми окремо вказуємо на принципово важливий для цілей цього дослідження факт, які повністю підтверджує та доводить концепцію Мішеля Фуко.

Йдеться про появу поліції в європейських країнах, причому наголосимо - про появу сучасної поліції з традиційними для сьогодення функціями оперативно-розшукової роботи та розслідування злочинів. На перший погляд, історія становлення сучасних служб поліції у країнах Свропи виглядає дуже дивно лише в силу того, що такі служби з'явилися запізно порівняно з іншими атрибутами держави.

Так, французька Сюрте з'явилася лише у 1811 році.

Англійський Скотланд Ярд заявився набагато пізніше - у 1829 році, і лише у вигляді одягнутих у цивільне вбрання поліцейських, які у блакитних фраках, сірих брюках та чорних циліндрах продефілювали через увесь Лондон до своїх нових поліцейських дільниць. Циліндри мали намір продемонструвати, що не солдати взяли на себе охорону безпеки, а саме цивільні особи - з огляду на занадто глибокі, але водночас викривлені з погляду сьогодення уявлення англійців про громадянські свободи, де зазначені уявлення уполіцейському нагляді вбачали загрозу громадянським свободам [7]. Лише у 1942 році з'явилися перші (у сучасному розумінні) детективи, які були вимушені для цілей зняти свої блакитні фраки та одягнути інше, більш непомітне цивільне вбрання [7].

Проте перше здивування усувається простим раціональним поясненням, чому в європейських держава сучасні поліцейські служби виникли на $30-50$ років після того, як в цих же країнах з'явилися сучасні в'язниці. Формально-класичний підхід відповідь на таке питання не дає, обмежуючись поясненням на кшталт «збільшення рівня злочинності».

Радикальний підхід, який покладено в основу цього дослідження, пояснює це по-іншому.

Так, сутність нового соціального контролю полягала у розподілі тіл нової політичної природи у просторі, чим займається не лише в'язниця, проте й інші дисциплінарні механізми, зазначені вище. 
Кожна дільниця соціального простору мала стати максимально зручною для проникливого паноптичного нагляду. Кожна дільниця простору мала кодуватися 3 метою розриву небажаних та небезпечних зв'язків будь-якого потенційно небезпечного індивіду, який хоч у чомусь йде проти капіталістичного розвитку або виявляє небезпеку такого руху «проти». Тому показники злочинності це лише формально-класичний зовнішній фасад проблематики. Сутність криється у тому, що масове поширення «виправних» в’язниць з усіма їх придатками та допоміжними інституціями призвело до суттєвого зростання кількості девіантів нової хвилі, за якими потрібно було постійно, регулярно та системно наглядати, що спонукало створити сучасні поліцейські служби 3 відповідним розгалуженим апаратом детективів, картотеками, агентіами під прикриттям, agents provocateurs та іншими придатками до поліцейських структур.

М. Фуко пише про цей період як про «історичний момент дисципліни»: «Народжується «політична анатомія», що є одночасно «механікою влади». Вона визначає, як можна підпорядкувати собі тіла інших, з тим щоб змусити їх не тільки робити щось конкретне, але діяти певним чином, iз застосуванням певних технік, з необхідною швидкістю і ефективністю» [6, с. 226].

Тому, що є надзвичайно важливим, що М. Фуко, аналізуючи сутність «виправної» в’язниці у структурі нового соціального контролю, вказує на те, що зводить нанівець традиційні класичні погляди формально-утопічної спрямованості на історію соціального контролю. Так, беручи до уваги матеріально-економічні передумови формування контрольних інституцій XIX століття, на перше місце випливає висновок, парадоксальний для прибічників традиційного (прогресивнофілантропічного) погляду на історію соціального контролю та національних системи кримінальної юстиції: у виправному покаранні, як це не дивно, власне відсутнє «виправне».

Тут ми наголосимо одну з найбільш, як на нашу думку, головних та важливих тез нашого дослідження: «виправне» («реабілітаційне», «виховне») у начебто «виправній» в’язниці - це одна 3 найбільших політичних містифікацій XIX століття, яка успішно пережила XX століття (хоч і зазнавши ударів з боку повторної хвилі позитивістських біологічних теорій у 1940-х - 1950-х роках та «кризу реабілітаційного ідеалу» у 1970-х роках) та, врешті-решт перейшла до XXI століття [8, с. 28-30].

Краще сказати, що за «виправним» насправді приховувалося та продовжує приховуватися саме «дисциплінарне», що становить важливий аспект дослідження сутності, форм та меж соціального контролю у XXI столітті: «За допомогою техніки виправлення прагнуть відновити не стільки правового суб’єкта, захопленого фундаментальними інтересами соціального договору, скільки покірного суб’єкта, індивіда, підкореного звичкам, правилам, наказам влади, яка постійно відправляється навколо нього і над ним та якій він повинен дозволити автоматично діяти в собі самому» [6, с. 189]. Тому, слушно запитує Фуко, що робить реформована в'язниця? Вона робить слухняними непокірних представників робітничого класу, залякує інших, прививає звички до дисципліни і порядку та в цілому відновлює втрачену ієрархію [6, с. 189].

Якщо у «виправній» в’язниці й була частка «виправного», то ця частка насправді виконувала функцію максимальної адаптації особи до умов капіталістичного суспільства. Мета нових дисциплінарно-каральних пристроїв полягала у відновленні людей із соціальними дефектами, проте не заради самих людей, а щоб вони могли більш-менш конкурувати у новому капіталістичному суспільстві: «Не лише в’язниця, проте й уся система кримінальної юстиції є частиною великого механізму більшої раціоналізації суспільних відносин у народженому капіталізмі» [2, с.23].

Так само, не зважаючи на філантропічні основу та численні (навіть масові) й зовні вагомі ідеологічні «реабілітаційні» «вкраплення», проекти «декарцерації» та «контролю у громаді» були реалізовані у XX столітті зовсім не з філантропічних мотивів, проте переважно 3 причин більшої економічної вартості ув'язнення. Більше того, як засвідчив час навіть «декарцерації» як такої не відбулося з огляду на показники застосування у світі ув'язнення як покарання та запобіжного заходу. Матеріалістичну основу усіх реформ соціального контролю (особливо кримінальної юстиції) приховати неможливо, тому подальша історія соціального контролю - це ніщо інше, як слушно підкреслив Коен, як «легітимізація в’язниці попри їі гучний провал [2, с. 20].

Говорячи про сутність модальності соціального контролю у другій половині ХХ столітті, варто наголосити на дуалістичному комплексному процесі.

Так, на фоні хвилі ухвалення та подальшого запровадження міжнародних та європейських інструментів прав людини та відповідного інституційного механізму, руху за обмеження ув'язнення та повернення від другої хвилі позитивізму до неокласицизму при обгрунтуванні цілей соціального контролю, мала місце інтенсифікація карцеральної інтервенції та посилення соціального контролю через ще більше розчинення дисципліни у тілі суспільства. 
Третя модель соціального контролю (друга половина XX століття), що, знов-таки, $є$ парадоксальним для прибічників класично-філантропічних поглядів на історію соціального контролю та національних системи кримінальної юстиції, виявилася ще більш песимістичною та водночас ще більш радикальною. Як слушно підкреслив Коен, «нова система соціального контролю ще більше служила вимогам капіталістичного порядку щодо здійснення контролю за робітничим класом, водночас вводячи в оману кожного (включаючи самих реформаторів), що зміни $\epsilon$ чесними, гуманними та прогресивними» [2, с. 22]. До того ж не варто забувати, що та сама «криза реабілітаційного ідеалу», яка мала місце у 1971 році завдяки епохальній та революційній праці Роберта Мартінсона про «Ніщо Не Працює», завдала більш ніж серйозного удару по формальнокласичних поглядах на сутність соціального контролю [8, с. 28-30].

Мало місце те, що Коен визначив як «ідеологічна атака», хоч ми більш схильні використовувати категорію «політико-каральна містифікація». Усі недоліки ув'язнення як усталеної форми соціального контролю намагалися врятувати за допомогою «індивідуального поводження» 3 девіантами, «case management» у діяльності пенітенціарних установ та служб пробації або через запровадження нових психологічних доктрин, які породили низку нововведень на кшталт більш гнучких та індивідуалізованих форм умовно-дострокового звільнення, розгалуження та поглиблення різних форм пробації та ювенальної юстиції, що, власне, дійшло і до нас в такому вигляді.

Проте, що потрібно наголосити, начебто активні альтернативи до ув'язнення, як засвідчив час та практика, виявилися пасивними додатками, що потягло за собою ще більшу диверсифікацію соціального контролю та залучення під парасольку механізмів соціального контролю нових груп задекларованих девіантів.

Відтак вже на початку нашого дослідження, беручи до уваги обгрунтовані позиції дослідників та користуючись цим методом, потрібно ставити конкретне питання щодо трансформації сутності, форм та меж соціального контролю на початку XXI століття. Продовжуючи думки Коена щодо трансформації соціального контролю, ми ставимо на порядку денному питання про четверту модель соціального контролю.

«Політичне захоплення тіла» - ось сутність соціального контролю у XIX столітті, межі якого важко визначити [6, с. 43]. Проте є очевидним, що політичне захоплення тіла у XXI столітті активно продовжується відповідно до розвитку соціальних структур та появи нових горизонтальних й вертикальних соціальних відносин та соціальних зв'язків, які надають підстави говорити про подальшу, більш мобільну, гнучку та технологічну транскарцерацію суспільства Постмодерна.

Свого часу саме завдяки Мішелем Фуко була розвинута ідея «карального (пунітивного) міста», яку сьогодні можна вважати основоположною для аналізу сутності та форм соціального контролю, меж соціального контролю, відмінностей між свободою та несвободою, а головне - для аналізу того, чи дійсно суспільство Постмодерну є справді вільним? I чи не нагадує суспільство Постмодерну одну велику гнучку тотальну інституцію з надзвичайно тонкими та прозорими мурами?

Мішель Фуко ставить базове запитання: «Якою $є$ відмінність між пунітивним містом та примусовим закладом? ... Реалізація «влади карати», розподіленої по всьому простору суспільства, ... забезпечує придушення злочину завдяки [численним] перешкодам, поставленим [вже] перед думкою про злочин, впливає невидимо і ненав'язливо. ... «Влада карати», яка поширюється по усій довжині соціальної мережі, діє в кожній їі точці та, в кінцевому рахунку, сприймається вже не як влада одних індивідів над іншими, а як безпосередня реакція всіх на кожного» [6, с. 191].

Концепцію «пунітивного міста» ще глибше розвинув американський соціолог Стенлі Коен, який сформулював орієнтири нового світоустрою у свій відомій праці «Візії соціального контролю. Злочин, покарання та класифікація», де «рunitive city» уявлялося Коеном як громада, побудована на проникливих механізмах соціального контролю з невизначеними кордонами між різними соціальними групами та категоріями громадян, де однією з основоположних категорій стало концепція «розкидування сітки» («Net Widening»).

Як на думку Коена, «punitive city» має наступні характеристики: 1) розповсюдження та проникнення соціального контролю далеко за стіни тотальних інституцій; 2) розмивання просторових меж, які позначають відмінності між свободою та несвободою; 3) розмивання меж, які позначають відмінності між ув'язненими та вільними особами; 4) розмивання меж, які позначають відмінності між злочинцями та «чесними громадянами»; 5) поява тотальних та інших контрольних інституцій, в яких «корекційне» втручання та контроль тонко оцінюються відповідно до «індивідуальних потреб», про які «клієнти» таких інституцій можуть не знати й навіть не здогадуватися; 6) розширення «контрольованого простору», що є результатом нечітких визначень «нормальності» та «девіантності». 
У вузькому розумінні Net Widening розуміється як наслідки широкого запровадження альтернативних ув'язненню покарань або спеціальних програм, спрямованих на максимально можливе відведення девіантів (здебільшого неповнолітніх) від кримінальної юстиції з метою недопущення стигматизації останніх та занурення їх до інституційної субкультури.

У широкому розумінні Net Widening зображується як результат, коли більша кількість осіб починає перебувати під парасолькою системи кримінальної юстиції внаслідок послідовних процесів, які Коен зобразив як «розставляння тенет», «звуження чарунок», «змішування» та «проникнення» $[9$, с. 285-288].

«Розставляння тенет»: за допомогою альтернативних покарань та «некаральних заходів» держава намагається контролювати тих осіб, які раніше не перебували у «групі ризику». Яскравим прикладом цього може служити масове запровадження в законодавстві та у практичній діяльності органів системи кримінальної юстиції категорії «ненормальна поведінка» або «підозріла поведінка» з відповідним системним відстеженням такої поведінки за допомогою засобів масового спостереження (з подальшим накопиченням отриманої інформації у базах даних).

«Звуження чарунок»: відбувається дисперсія соціального контролю не лише за кількісними, але й за якісними критеріями. Не тільки дедалі більше людей підпадають під дію механізмів соціального контролю, проте водночас відбувається інтенсифікація застосування санкцій за порушення певних правил або умов. Тобто, у подальшому ми можемо очікувати не тільки визначення «ненормальної поведінки», але й розширення цього концепту, виділення численних різних типів «ненормальних людей» та запровадження перманентно обновлюваної типології та класифікації проявів «ненормальної поведінки». У площині функціонування пенітенціарної системи вже сьогодні це проявляється в діяльності служб пробації, де прикладом може служити посилення умов пробаційних ордерів, збільшення кількості зобов'язань, умов та обмежень, що покладаються на піднаглядних «клієнтів» служб пробації.

«Змішування»: як результат зазначених вище тенденцій, відбувається злиття кордонів між «інституційними» та «не-інституційними» заходами впливу на злочинну, девіантну, «підозрілу», «нестандартну», «нетрадиційну» або «незвичну» поведінку. Більше того, відбувається злиття кордонів між тим, що є покаранням й тим, що таким не є. Внаслідок цього стає вже зовсім незрозумілим, хто саме «заплутався» у тенетах соціального контролю. Майже усі, чия поведінка якось виявилася «ненормальною», стають такими.

«Проникнення»: внаслідок зазначених вище соціальних трансформацій створюються сприятливі умови для якісного збагачення пенітенціарної системи як дисциплінарного проекту. Нові контрольні механізми аж ніяк не підміняють в'язницю як соціально-контрольну інституцію, вони роблять непомітним розширення дії інституційного контролю. Водночас на порядку денному гостро питання про будь-яке «реабілітаційне» спрямування системи кримінальної юстиції через відсутність потреби у будь-якому «реабілітаційному лицемірстві» [10, с. 145-153].

Таким чином створюються умови для появи карцерного суспільства.

3 моменту виходу цієї праці Стенлі Коена ії актуальність не лише зросла, проте й примушує заявити про необхідність більшої уваги до такого погляду, що ми й пропонуємо у нашому дослідженні. Зазначене дослідження Коена в умовах сьогодення є більш ніж актуальним з огляду на впливи процесів глобалізації, які примушують переглянути сутність, форми, методи та цілі соціального контролю у суспільстві Постмодерну. Водночас актуальність загострюється через проблему дотримання основоположних прав людини, закріплених у міжнародних та європейських стандартах, внаслідок поширення соціального контролю як політичного феномену (передусім це стосується права на повагу до приватного та сімейного життя (стаття 8 Конвенції про захист прав людини)).

Розвиваючи погляди Коена, варто, передусім, зазначити, що сучасні маркери соціального контролю $є$ менш чіткими та більш прозорими, аніж їх аналоги XX століття. Кордони між тотальними інституціями та їх сателітами, іншими контрольними механізмами та «вільним суспільством» дедалі більш розчинаються у численних начебто просоціальних, філантропічних та реабілітаційних ініціативах під гаслами «декарцерації», які, з одного боку, спрямовані на мінімізацію ролі держави, проте, з іншого, свідчать про посилення масштабів та глибини «оброблення» політичного тіла людини з метою, щоб ця ж сама людина була максимально корисною у ринкових відносинах нового тисячоліття.

Фуко у своїй праці «Наглядати й карати» підкреслив тезу, яка була надзвичайно актуальною для XX століття, проте набуває ще більшої актуальності саме у суспільстві ХХІ століття. Йдеться про 
«одиницю дисципліни», якою є не територія (одиниця панування), не місце (одиниця розташування), а «ранг»: місце, займане в класифікації, місце перетину рядка і стовпця, інтервал в ряду інтервалів, які можна переглянути один за одним: «Дисципліна - це мистецтво рангу і техніка перетворення розміщень [6, с. 212-213]. Дисципліна індивідуалізує тіла за допомогою локалізації, яка означає не просте закріплення їх на певному місці, проте їх розподіл та циркуляції у соціальних відносинах.

Розподіл по рангах, як наголошує Фуко, грає подвійну роль. 3 одного боку, ранг «визначає відхилення від правил, встановлює ієрархію якостей, знань та навичок» [6, с. 265]. 3 іншого боку, ранг карає та винагороджує: «Дисципліна винагороджує присудженням рангу. Дисципліна карає, знижуючи в ранзі. Ранг сам по собі служить нагородою або покаранням» [6, с. 265].

Стандартизація виробництва та продукції внаслідок стандартизації індивідів була важливою складовою Великого дисциплінарного проекту XIX століття. Так, Фуко, підкреслюючи поширення дисципліни у суспільстві XIX століття, наголошував не лише на поширенні традиційних контрольних пристроїв, проте й на широкому запровадженні стандартизації будь-якої сфери діяльності та запровадженні нових формалізованих соціальних ієрархій: «Організовуючи «місця» і «ранги», дисципліна створює комплексні простори: одночасно архітектурні, функціональні та ієрархічні. Простори, які забезпечують фіксовані стани та переміщення. Вони вимальовують індивідуальні сегменти та встановлюють операційні зв'язки. Вони відводять місця та визначають цінності. Вони гарантують покору індивідів, проте водночас гарантують кращу економію часу і жестів. ... Першою великою операцією дисципліни $\epsilon$, таким чином, утворення «живих таблиць», що перетворюють безладні, даремні й небезпечні маси на впорядковані множини» [6, с. 216].

Варто нагадати, що соціальний контроль XIX століття характеризувався зростаючою диференціацією та класифікацією девіантних та інших цільових груп на окремі типи і категорії, кожна 3 власним набором наукових знань та відповідними акредитованими «експертами».

Так само XXI століття характеризується ще більш зростаючою диференціацією та класифікацією усіх інших соціальних груп на окремі типи та категорії, причому так само кожна соціальна група має власний набір наукових знань та відповідних акредитованих «експертів», які на регулярній основі проводять «вільним громадянам» та «чесним платникам податків» регулярні постійні «іспити», які, що важливо підкреслити, Мішелем Фуко також свого часу було подано як найбільш тонкий та невидимий інструмент соціального контролю та невід'ємну складову нового дисциплінарного простору: «Іспит поєднує техніки наглядової ієрархії та нормалізучої санкції. Іспит робить індивідів видимими, завдяки чому їх можна диференціювати й карати. Тому у всіх дисциплінарних механізмах іспит - досконалий ритуал. У ньому поєднуються церемонія влади і форма досвіду, застосування сили й встановлення істини. У центрі дисциплінарних процедур іспит демонструє підпорядкування тих, хто сприймається як об’єкти, і об'єктивацію тих, хто підпорядковується» [6, с. 270].

Наголосимо, що соціальний контроль ХІХ століття - це розбудова нової ієрархії капіталістичного зразка на противагу архаїчній формалізованій, напіврелігійній ієрархії Середньовіччя, адже нова чітка й міцна ієрархія - це основа й водночас мета соціального контролю. У XIX столітті «ранг» - це вже не формальний статус, закріплений державою або церквою у певному документі «від давен», який зобов'язує частину суспільства виказувати певну повагу носієві такого рангу та водночас свідчить про високий формальний авторитет його носія. Проте у XXI столітті ранг - це всього-навсього обов' язкова перепустка до потягу, який називається «певне коло соціальних відносин», після подорожі на якому потрібно купувати новий квиток та сідати у наступний потяг по іншому, вищому колу соціального життя. Соціальний контроль XXI століття - це адаптація та оновлення ієрархії у відповідність до нових соціально-економічних умов Постмодерну, у тому числі за допомогою більш тонких інструментів, якими є ще більша стандартизація, ще глибший розподіл по рангах та численні, регулярні й масштабніші «іспити». Відтак, відповідно, система кримінальної юстиції продовжує бути частиною великого механізму більшої раціоналізації суспільних відносин у ринкових відносинах Постмодерну.

У XXI столітті швидкість та обсяги соціального контролю збільшуються, і XXI століття надає приклади розширення кількості девіантів та їх класифікації.

Так, з одного боку, збільшення класифікаційних груп злочинів та, відповідно, злочинців, - явище, яке $\epsilon$ нормальним для розвитку будь-якого суспільства, на що також звертав увагу Мішель Фуко. Так, якщо злочинці XVII століття- це «люди виснажені, голодні, які живуть одним моментом, розпорошені» та «тимчасові злочинці», то вже у XVIII столітті - «вертляві, хитрі, розсудливі бестії» та «маргінали» [6, с. 108-109]. Продовжуючи цю думку, можна наголосити, що поява нових горизонтальних та соціальних зв'язків, дроблення соціальних відносин та утворення нових общин i 
соціальних груп зумовлює появу нових класів девіантів у межах цих груп та общин (пригадаємо ідею Еміля Дюркгейма щодо «монастиря святих»). Навіть від злочинця ХХІ століття вимагається знання нових гаджетів, електронних мереж та відповідних баз даних, навіть якщо вони перебувають у в'язниці й навіть якщо за своєю спеціалізацією на волі він відноситься до насильницьких злочинців.

Крім того, проте саме XXI століття свідчить не лише про збільшення кількості типів й видів злочинців, проте й про розширення класів девіантів, а також про зникнення чітких кордонів між злочинами та іншими проявами девіації.

Так, гасло розвитку Європи - «єдність у різноманітності» - обумовило перехід від полярності «чорний - білий» до безлічі різнокольорових відтінків, де стверджуване посягання на будь-яке «нестандартне» дозволяє записати до кола девіантів як саму особу, яка посягає, так і особу, яка $€$ об’єктом посягання.

Наприклад, формальне визнання в країнах Європи більших прав та можливостей за представниками ЛГБТ-спільноти автоматично призводить до віднесення до кола девіантів будьяких активістів, які у будь-яких формах висловлюють або демонструють негативне ставлення до ЛГБТ-спільноти. Проте й водночас самі представники ЛГБТ-спільноти для більшості населення країн Свропи (і не лише Східної Свропи) самі не позбавилися тавра девіантів та являють, як на думку більшості населення, ідеологічну загрозу «традиційним сімейним цінностям».

Так само, представники екологічних рухів, які проводять радикальні екологічні акції, можуть вважатися девіантами та навіть за певних умов стають злочинцями, проте й, з іншого боку, особи, проти яких спрямовані такі екологічні акції, також нерідко потрапляють до кола девіантів лише в силу того, що вони виступають проти захисту навколишнього середовища i, як наслідок, отримують стигму «ворогів більш екологічного майбутнього планети».

Щодо посилення соціального контролю у сфері цивільної юстиції, як приклад можна навести посилення соціального контролю за платниками аліментів, або, краще сказати, за особами, які ухиляються від сплати аліментів. В Україні за останні роки було ухвалено низку законів, а головне проведено масштабну всеосяжну інформаційну кампанію на телебаченні та в усіх соціальних мережах, спрямовану на максимально можливе таврування зазначених осіб. Обсяг та ступінь стигматизації «аліментників» створили враження, що саме «аліментники» $є$ головною девіантною групою в українському суспільстві, де начебто випадково зникли інші види девіантної поведінки. Потрібно наголосити, що тут важливим $є$ не стільки інформаційна кампанія, стільки суворі санкції до «аліментників», до яких за несплатну аліментів застосовуються суто кримінальні за своєї природою санкції у вигляді заборони у праві на виїзд за кордон, заборони керування автомобілем, заборони користування вогнепальною мисливською, пневматичною та охолощеною зброєю та заборона полювати [11]. Проте у контексті цього дослідження буде питання про створення фактично на рівному місці нових груп девіантів, які суворо караються державою, та поміщення таких девіантів до додаткових контрольних пристроїв.

Щодо системи кримінальної юстиції як класичної форми соціального контролю, то іншим прикладом, який доводить теорію «дроблення класів девіантів» $є$ сучасна пропагандистська кампанія щодо профілактики сімейного насильства. Замість «особи, яка вчиняє сімейне насильство», додатково 3'явилися «кривдники» й навіть «діти-кривдники». Дія законодавства про запобігання та протидію домашньому насильству наразі поширюється на будь-яких родичів або інших осіб, включаючи наречених. Причому «насильство» - це не лише фізичне або статеве насильство, проте й широкий, а головне детально не визначений спектр заборонених дій, що включає десятки форм - від заборони навчатися до примушування до праці. Психологічне насильство - це також невизначений спектр дій [12]. Отже, внаслідок встановлення десятків нових форм девіації з'явилися сотні нових видів правопорушників.

Іншим прикладом зі сфери кримінальної юстиції може служити таке.

Так, дедалі більша популярність концепції динамічної безпеки, запровадження self-management у в'язницях та обов'язкове включення «клієнтів пробації» до здійснення оцінки ризиків цих же «клієнтів» вказують на появу вельми цікавого феномену для аналізу сучасної моделі соціального контролю, адже об'єкт контролю набуває подвійної природи. 3 одного боку, він залишається об'єктом контролю, проте водночас він набуває дуалістичного статусу, який у чомусь підносить його до статусу суб'єкту контролю. 3 формально-класичного погляду - це начебто «прояв гуманізації», а також «надання процесу виконання покарань більш гуманного обличчя та індивідуальності». Проте 3 погляду радикального підходу такі ініціативи можна розглядати не інакше як поширення більш тонкого та проникливого, майже непомітного контролю. Добровільна, непримусова, м'яка участь 
об’єкту контролю у процедурі класифікації - що може бути краще для системи соціального контролю? Водночас відмова об'єкту контролю (клієнта пробації) добровільно «впасти» у ці додаткові тонкі та завуальовані мережі автоматично призводить до нового, додаткового таврування вже й так затаврованого девіанта як такого, що своєю впертою відмовою бути ще більше підконтрольним демонструє «явно нерозумний цинізм до виказаної йому високої довіри з боку держави», а відтак - більшу «явну більшу небезпеку» для системи соціального контролю порівняно 3 тими, хто «добровільно» більш глибоко занурився до таких мереж.

Отже, у XXI столітті соціальний контроль має явні ознаки біфуркації. Ми можемо спостерігати дуалістичний процес, коли заклики щодо посилення прав людини, яким минулого століття не приділялося уваги, заклики щодо дотримання кордонів та меж особистого простору та інші вимоги «боронити свободу» існують паралельно з розвитком нових, більш технологічних форм захоплення цієї свободи.

Причому держава, легко дозволяючи собі проникнення до особистого життя людини, вельми нервово реагує на будь-які спроби людини проникнути до «особистого життя» держави, не цураючись застосовувати форму реакції, характерну для часів підкорення Дикого Заходу у США, а саме застосування економічних стимулів з яскравим гаслом «Wanted». Цікавим прикладом такої майже середньовічної реакції є офіційне оголошення Державним департаментом США винагороди у розмірі до 1 млн. доларів за надання інформації, яка допоможе заарештувати та притягнути до відповідальності громадян України Артема Радченка та Олександра Сременка за стверджувану участь у транснаціональній організованій злочинності, зокрема, кіберзлочинності.

Тому, на нашу думку, є більш ніж очевидним, що проблематика нової моделі соціального контролю у XXI столітті ще тісніше, аніж раніше, пов'язана з категорію свободи.

Якщо Фуко та Коен піддали аналізу категорію «пунітивного міста», підкреслюючи, що суспільство XX століття свого часу перетворилося на карцерне суспільство, то XXI століття надає приклад природньої реакції homo sapiens щодо повернення втраченої свободи, яка у новому тисячолітті виявилася остаточно переплетеною з намаганням створити навколо себе максимально безпековий простір (як буквальний (територіальний), так і віртуальний (інформаційний). Водночас краще сказати, що йдеться навіть не безпековий, а саме «зручний» простір, адже ідеологію споживання також потрібно враховувати. Відтак саме прагнення $є$ таким, що має змінену сутність в силу спотворення самої «безпекової» («убезпеченої») свободи культурою споживання.

Як наслідок, ми говоримо не лише про те, що суспільство перетворилося на дуже дивну форму закамуфльованої несвободи з нечіткими, розмитими кордонами.

Ми також говоримо про те, що знизу суспільства такої закамуфльованої несвободи час від часу 3'являються «бульбашки» «безпекової» або «убезпеченої» «споживацької» свободи, які піднімаються на поверхню, керуючись природнім імпульсом та, як наслідок, створюють «гетто свободи», «міські села», «міські форти», або «захисні простори міста». Сучасне постіндустріальне суспільство має безліч способів тримати homo sapiens під своєю владою, причому головною «страшилкою» для homo sapiens XXI століття стало поняття «небезпеки споживацького дискомфорту», в якій homo sapiens буде позбавлений нових гаджетів, цікавих видовищ, сучасного комп'ютерного забезпечення (хоча, звичайно, базові цінності повернулися значною мірою через епідемію коронавірусу). Сьогодні, якщо homo sapiens хоче бути «вільним», він має бути «убезпеченим», але водночас він також хоче бути позбавленим, коли йому зручно, відчуття належності до цього ж суспільства.

Бауман слушно звертає увагу на одну важливу рису суспільства Постмодерну, повторювану 3 майже незмінною регулярністю: підозрілість по відношенню до інших, нетерпимість до відмінностей, неприязнь до чужинців, вимоги, щоб їх «відокремили» або взагалі не допускали до міста, а також істерична, параноїдальна заклопотаність «законністю і порядком»- все це сягає вищої точки в найбільш стандартизованих, сегрегованих в расовому, етнічному й класовому відношенні, однорідних місцевих спільнотах [[3, с. 70]. Такий собі приклад героя Сильвестра Сталлоне з кінострічки «Рембо. Перша кров», де уся кривава драма стає наслідком імперативу з боку місцевого шерифу у вигляді наказу «Йди звідси. Не тому, що ти поганий. Йди геть лише тому, що ти - чужинець. А чужинців тут не люблять». Причому, наголосимо, це лише кінець 1970-х років. I Рембо - білій вільний громадянин серед таких само білих вільних громадян. Що ж тоді можна казати про мегаполіс початку XXI століття, колективне психічне здоров'я якого вже спотворено «хвилями злочинності», «тероризмом», «нелегальними мігрантами» та іншими «жахами» Постмодерну?

Девіантність, як із злочинність, - це природне явище, нормальні показники якої, за загальноприйнятою думкою Дюркгейма, є ознакою здорового суспільства. Проте у суспільстві 
Постмодерну соціокультурні та духовно-моральні завдання стоять далеко не на першому місці, в результаті чого у індивідів зникає почуття спільності, а за ним - дух солідарності, що, власне, повністю підпадає під ознаки аномії, про яку писали Еміль Дюркгейм та Роберт Мертон: «Суспільство може існувати лише тоді, коли між його членами існує достатня ступінь однорідності [13]. Тому невипадково Бауман, аналізуючи сутність соціального контролю суспільства Постмодерну, наголошує: «Нічого дивного: у подібних спільнотах відсутне почуття спільності» [3, с. 70].

Відгородивши своє «каральне місто» від решти світу, проте відчувши брак свободи та водночас перебуваючи у стані безпекової істерії, суспільство Постмодерну починає створення не менш «каральних районів» у межах такого міста: «Еліти самі обрали ізоляцію і платять за неї охоче й щедро. Решта населення «відсікається» насильно і змушена платити високу культурну, психологічну і політичну ціну за свою знов придбану ізоляцію. Ті, хто не здатні зробити відокремлене існування предметом вільного вибору та сплатити вартість своєї безпеки, стають жертвами сучасного еквівалента «обгородження» періоду пізнього Середньовіччя та раннього нового часу. Їх просто залишають «за парканом», не питаючи згоди, та забороняють доступ до ще учора доступних «загальних» місць» [3, с. 36].

Вельми яскравим прикладом такого стану справ є кінострічка «13 район», де наочно представлене те, що поки ще багатьма сприймається як фантастика. Так, за сценарієм, у Парижі 2010-го року через неконтрольований розгул злочинності деякі особливо небезпечні райони столиці перетворені на закриті зони та відгороджені від благополучних кварталів високим бетонним муром. За ним - зовсім інше життя, де девіація стає абсолютною нормою (і навпаки): тут відкрито й безкарно процвітає торгівля наркобізнес й торгівля зброєю, тут навіть діти не виходять з будинку без зброї, не працюють школи й медичні заклади, поліція захищає лише себе, або ж, навпаки, сама поліція являє форму організованої злочинності. Найбільш іронічним $є$ те, що ця кінострічка - про події 2010 року. Між тим почалася третя декада наступного століття. Безумовно, це - політична напівфантастика. Проте, з іншого боку, це водночас політична напівреальність.

Бауман слушно зауважує: «Сьогодні страхи, типово «міські страхи», на відміну від тих, що привели колись до виникнення міст, зосереджені навколо «внутрішнього ворога». Подібний страх породжує занепокоєння не тільки цілісністю й неприступністю всього міста - як колективної власності і колективної гарантії безпеки кожного - скільки ізоляцією і зміцненням власного житла всередині міста. Мури, колись оточували місто, тепер хрест-навхрест зорали територію міста в усіх напрямках. Квартали із системами спостереження, ретельно контрольовані громадські місця з обмеженим доступом, озброєні до зубів охоронці біля воріт і дверей з дистанційним керуванням - все це сьогодні направлено проти «небажаних» співгромадян, а не іноземних військ, розбійників, грабіжників та інших невідомих небезпек, що підстерігають вас за міськими брамами» [3, с. 72].

Сучасне місто $€$ карцерним не лише тому, що воно пронизано вертикальними й горизонтальними зв'язками технологічного соціального контролю. Карцерність - це не лише зовнішня характеристика сучасного соціуму, проте й характеристика внутрішньо-психологічна. У сучасному мегаполісі головною стратегією виживання стала не спільність, а ізоляція й відокремлення від інших: «Питання про те, чи подобається вам ваш сусід чи ні, не є більше актуальним. Тримайтеся від сусідів подалі, i ви не зіткнетеся з цією дилемою і з необхідністю вибору; вам просто не трапиться нагода обирати між любов'ю та ненавистю» [3, с. 72-73].

Внаслідок викладеного вище сучасній державі та іншим акторам (у тому числі приватним), які змагаються з державоюза владу (у тому числі транснаціональну), навіть не потрібно витрачати час, гроші, інформаційну пам'ять та інші ресурси на неквапливе занурення суспільства до більш тонких мереж технологічного соціального контролю. Суспільство саме, за власний кошт і за власною ініціативою зробить все, щоб відчути себе «убезпеченим» проти «таємничих чужинців», «небезпечних бродяг», «підступних збоченців», «агресивних хижаків», «девіантів» або «осіб, які посягають на наші традиційні цінності». Достатньо лише запустити чергову хвилю moral panic щодо «розгулу злочинності», «стрімкого поширення девіації» або «появи загроз нашим цінностям» взагалі або у певній сфері. У подальшому державі потрібно, користуючись своїм монопольним правом щодо «необхідності розслідування злочинів», «міркуваннями національної безпеки» або «метою захисту суспільної моралі», лише вилучити у приватних акторів будь-яку необхідну державі інформацію, накопичену приватними особами їхніми зусиллями і за їхній же кошт.

Камери відеоспостереження є більш ніж яскравим прикладом зазначеного вище та феноменом суспільства Постмодерну. 
Так, за ініціативою й за кошт самих громадян начебто «Вільного Міста N» камерами відеоспостереження масово обладнуються вулиці, провулки, сквери, подвір'я, поверхи, ліфти, підвали, де «свобода» сором'язливо виглядає зі спини «убезпечення».

Наразі на кожні 100 осіб у США перебуває 15,3 камер відеоспостереження, у Китаї - 14,4 камер, у Сполученому Королівстві - 7,5 камер, у Німеччині - 6,3 камер, у Нідерландах - 5,8 камер, в Австралії - 4 камери, в Японії - 2,8 камери, у Франції - 2,5 камери, у Південній Кореї - 2 камери [14]. Причому ще у 2014 році у США цей показник був лише 12,5 камер на 100 осіб, а в Китаї2,7 камер [15]. Враховуючи, що поширення камер відеоспостереження у приватному секторі відслідкувати майже неможливо, можна висловити обгрунтоване припущення, що цей показник можна впевнено збільшити у декілька разів.

У світовому рейтингу 18 міст з найбільшою кількістю камер відеоспостереження на душу населення розташовані в Китаї, що, звичайно, може надавати підстави говорити про Китай як про країну, де населення живе в інформаційній в'язниці. Проте не варто забувати, що на 3-му місці у списку найбільш контрольованих за допомогою камер відеоспостереження міст посідає Лондон, а 16-те місце - індійське місто Гайдарабад [16]. Так само не варто забувати, що перше місце за кількістю камер спостереження в цілому на країну посідають США, а третє - Сполучене Королівство. Станом на сьогодні на 7,4 млрд. жителів планети припадає 770 млн камер відеоспостереження (10,4 камер на 100 осіб). Прогнозується, що у 2021 році кількість камер відеоспостереження перейде відмітку понад 1 млрд. (понад 14 камер на 100 осіб) [16].

Проте найбільш парадоксальним $є$ те, що кримінологічні дослідження аж ніяк не виявляють кореляції між збільшенням камер відеоспостереження та зниженням рівня злочинності. Так, Ларс Свендсен слушно наголосив, що Лондон належить до переліку найбільш контрольованих за допомогою камер відеоспостереження міст, проте камери відеоспостереження допомогли розкрити всього 3\% пограбувань на лондонських вулицях [5, с. 270].

Дослідження впливу камер відеоспостереження на розкриття злочинів у місті Даллас (США) продемонструвало збільшення розкриття злочинів на $2 \%$, проте водночас порушило питання щодо економічної вартості такого відеонагляду [17].

Кримінологи Брендон Уелш та Девід Фарінгтон проаналізували 44 дослідження щодо впливу камер відеоспостереження на рівень злочинності та дійшли вельми суперечливих висновків. Так, 15 досліджень вказували на суттєве зменшення злочинності. 3 дослідження дійшли висновків, що камери відеоспостереження, як це не дивно, навіть сприяють зростанню злочинності. 23 дослідження показали відсутність суттєвого впливу камер відеоспостереження на рівень злочинності [18]. Проте серед 15 досліджень, які продемонстрували зниження рівня злочинності через камери відеоспостереження, 14 базуються на британських даних, а Британія, як ми вже зазначали вище, $є$ лідером за кількістю камер на душу населення. Гадаємо, що такий успіх камер відеоспостереження пов'язаний виключно з перенасиченням британського суспільства відеонаглядом, коли камери відеоспостереження не мають задекларованого загальнопревентивного ефекту, а лише дозволяють поліції суто технічно відслідкувати переміщення особи з сектору А до сектору Б.

Проте камери спостереження - це лише невелика частина сучасного глобального технологічного паноптикону. Наприклад, посилення безготівкового обігу та масовий перехід населення на безготівкову форму оплати за будь-що - це ще один прояв «інформаційного прив'язування» будьякого члена суспільства до свого соціально-інформаційного кластеру, чому особливо сприяла епідемія коронавірусу.

Інший приклад - масовий примусовий перехід чиновників та деяких інших категорій осіб на електронне декларування майнового стану. Так, безумовно, маючи просоціальну (антикорупційну) спрямованість, цей перехід все одно має ознаки соціального контролю та повинен бути поміщений до переліку прикладів для цілей нашого дослідження.

Ще одне явище, яке може служити прикладом м'якого розривання усталених соціальних зв'язків та начебто «добровільного», проте водночас примусового занурення громадян до більш тонких мереж соціального контролю та поміщення цих громадян до нових електронних кластерів. Це - популярні сьогодні ідеї на кшталт «держава у смартфоні». 3 одного боку, що може бути краще для пересічного громадянина, аніж звільнення його від армії «кровожерливих бюрократів» через запровадження електронних сервісів. Проте така свобода має важливий політичний наслідок у вигляді абсолютного заглиблення громадян до електронних баз даних, необмежений доступ до який має та ж сама держава або інші впливові актори. Прикладом може служити нещодавні скандал, пов'язаний зі продажом персональних даних сотень тисяч українців через меседжер Telegram, де будь-хто міг купити 
будь-які персональні дані, включаючи паролі від електронної пошти та відомості щодо банківських рахунків [19]. Отже, державі достатньо посилити бюрократичну складову своїх публічних сервісів та одразу ж запропонувати «шлях до звільнення від бюрократії» у вигляді добровільної утилізації громадянами своєї власної свободи.

Як ще один приклад можна навести зростання обсягів поштових сервісів, особливо під час пандемії коронавірусу та відповідного карантину, що може служити приладом вельми успішного союзу держави та великого бізнесу у війні проти свободи (щодо України додатково зауважимо, що за час карантини доходи постачальників готової їжі зросли на 70\%) [20].

У цьому контексті на особливу увагу заслуговує важлива для цілей цього дослідження деталь. Так, у 2016 році до п'ятірки найбільш заможних людей планети увірвався американський бізнесмен Джефрі Безос з його компанією Amazon. У 2017 році Безос посідав вже третю сходинку. У 2018 році Безос посів перше місце, яке й тримає до цього часу, ставши першим в історії людства «сантимільярдером», тобто власником статку в понад \$100 млрд. Станом на 12.11.2018 Безос володів понад \$141 млрд.

На нашу думку, приклад успіху Amazon свідчить про важливу зміну пріоритетів розвитку суспільства Постмодерну та цінностей людей такого суспільства.

Комфорт? Так. Зручність? Так. Краща ціна? Так. Економія часу? Так.

Проте що з відповідними інформаційними базами? Так, лише у 2018 році служба доставки Amazon Prime охопила 100 млн. абонентів по всьому світу, що, звичайно, пов'язане з накопиченням відповідних баз даних. Тому можна поставити риторичне питання: невже найбагатший транснаціональний актор, який володіє базою даних щодо сотень мільйонів людей, не становить загрозу їх свободі?

I на продовження цієї тези можна додати важливу деталь, яка має принципове ідеологічне значення для цілей нашого дослідження.

Станом на травень 2017 року у Джефрі Безоса знаходилося 79 млн. акцій Amazon. На другому місці серед акціонерів Amazon посідала транснаціональна корпорація Vanguard Group (друга у США компанія у сфері інвестиційної діяльності) з 25 млн. акцій.

У свою чергу, Vanguard Group станом на 2015 рік володіла 14\% статутного фонду Corrections Corporation of America (нині-CoreCivic)) [21]. Станом на 2016 рік CoreCivic посідала найвищу сходинку серед усіх в'язничних корпорацій усвіті. Наразі CoreCivic управляє понад 65 пенітенціарними установами на федеральному та національному рівнях із загальною кількістю понад 90 тис. місць у 19 штатах США.

Отже, в сучасному світі найбільший у світі капітал значною мірою опосередковано базується на праці ув'язнених, які утримаються під вартою у приватних в'язницях.

Повертаючись до теми нашого дослідження, варто наголосити, що сьогодні йдеться про появу супертехнопаноптикону для суспільства XXI століття з новими формами дисципліни, новими кластерами, новими рангами та новими іспитами.

Ця теза може здаватися занадто радикальною, проте як можна назвати сучасне «вільне» суспільство, де Великий Брат прискіпливо та постійно дивиться на людину за допомогою: 1) камер відеоспостереження; 2) прослуховування телефонних переговорів; 3) ознайомлення з регулярною та електронною поштою; 4) збирання інформації про зарубіжні та внутрішні поїздки; 5) збирання інформації про будь-які форми участі у будь-яких формах протесту проти влади; 6) використання супутників та інших новітніх інформаційних технологій; 7) збирання інформації про будь-які прояви «девіантної» або взагалі «ненормальної» поведінки; 8) фіксування за допомогою камер відеоспостереження будь-яких проявів поведінки на вулицях та будь-яких інших місцях (навіть у ліфтах та поверхах жилих будинків); 9) збирання інформації про будь-яку купівлю будь-якої речі? Гадаємо, що це - ідеал паноптичного устрою, про який навіть й не міг мріяти Джеремі Бантам з його «Паноптиконом».

Свого часу Дж. Оруелл в його антиутопії «1984» слушно наголосив: «Звідки взятися гаслу «Свобода - це рабство», якщо скасоване саме поняття свободи?». «Слово «вільний» в новоязі залишилась, проте його можна використовувати лише в таких висловленнях, як «вільні чоботи», «туалет вільний». Воно не використовувалося у старому значенні «політично вільний», «інтелектуально вільний», оскільки свобода думки та політична свобода не існували навіть як поняття, а тому не потребували визначення». тому, вважаємо, що сьогодні замало говорити про «відсутність свободи».

Проте навіть зазначене вище занурення до більш технологічних та невидимих контрольних механізмів - це лише частина проблематики, адже «поряд з великою технологією телескопа, лінзи, 
пучка світла, яка складала одне ціле з підставами нової фізики і космології, існують малі техніки численних i перехресних наглядів, поглядів, які повинні бачити, залишаючись невидимими» [6, с. 259-250]. Головне $\epsilon$ те, що убезпечення суспільства Постмодерну - це результат угоди, в обмін на яке людина віддає свою свободу, яка із радістю забирається сучасними механізмами соціального контролю: «Ми радісно сприймаємо 3 майже мазохістичним задоволенням, що «1984» вже настало» [2, с. 47]. Тому не можна не погодитися із Еріхом Фроммом, який зазначив, що сучасне суспільство - це нація політиків, яка думає лише про те, щоб бути вільними [22, с. 288], перетворюючись на рабів свободи.

Щодо позиції Ларса Свендсена, то з ним не можна погодитися у тому, що стремління сучасної людини технологічного суспільства добровільно віддати свою свободу можна вважати «варіантом добровільного рабства» [5, с. 267]. Ми б не ставили знак рівняння між рабством на несвободою. Проте сама ідея не може не заслуговувати на увагу.

Водночас Свендсен слушно вказує на те, що сьогодні багато людей факт відсутності спостерігання за ними лякає більше за перебування під цілковитим наглядом [5, с. 261]. Продовжуючи та підтримуючи таку думку, хотілось б ще раз наголосити на цікавому історичному прикладі.

Так, коли на XIX столітті у Британії створювалася сучасна професійна поліція, то все суспільство встало проти іiї створення, адже на думку тодішнього англійського джентльмена сам факт існування поліції в суспільстві свідчить про тотальний, всеохоплюючий, безмежний (по тодішнім міркам) соціальний контроль, а тому поліція не може мати місця у вільному суспільстві вільних людей, для яких свобода $є$ фундаментальною цінністю. Минули два століття, і Велика Британія посідає третє місце в світі за кількістю камер відеоспостереження на душу населення, а Лондон посідає третє місце в світі за цим же показником в переліку міст з найбільшою концентрацією камер відеоспостереження.

Отже, можна обгрунтовано говорити завойована «свобода від» також втрачається сьогодні у різних формах та проявах. Наслідком може бути те, що наочно представлено Свендсеном в його книзі: «Мешканці лише на позір є вільними: навіть якщо вони вільні чинити те, що хочуть, вони не мають впливу визначати те, чого бажають [5, с. 21]. Не можна також не погодитися із Фроммом щодо того, що людина отримала «свободу від», але не отримала «свободу для», тобто свободу бути собою, бути продуктивною. тому людина і почала втікати від свободи» [22, с. 382-383]. Саме такий стан справ повинен пригортати увагу з огляду на можливість сучасних технологічних засобів, пристроїв та технологій впливати на масову свідомість та «формувати волю», внаслідок чого ми живемо у приховано, але суворо контрольованому суспільстві з однаковим для усіх співмешканців набором цінностей.

Наприкінці цього дослідження, ми мусимо повернутися до питання трансформації форм соціального контролю та «Великої інкарцерації». Так, «виправна» в’язниця як центральний елемент системи соціального контролю у XIX столітті поступився у XX столітті місцем комбінації в'язниці та інституційних додатків, проте соціальний контроль обох століть базувався на декларативній ідеї «виправлення» девіантів (здебільшого «виправлення через працю або інші форми соціально корисної діяльності). Проте сьогодні потрібно зробити наголос: система соціального контролю Постмодерну не може бути ідентичною системі соціального контролю XX століття, оскільки сучасний капіталізм не зацікавлений у таких обсягах праці та стимулює масове безробіття [4, с. 21]. Навіщо, наприклад, авіакомпаніям наймати вільних працівників на роботу, якщо цю ж роботу можна доручити ув'язненим у приватних в'язницях? Як наслідок, постає питання щодо «праці як засобу виправлення девіантів» або, краще, сказати про відсутність головного «засобу виправлення». Саме у XXI столітті соціальний контроль має сміливість публічно оголосити про відсутність його закріпленості навіть в ідеологічний філантропічних «вкрапленнях».

Висновки до даного дослідження і перспективи подальших розвідок у даному напрямку.

Підсумовуючи викладене вище, можна підсумувати, що категорія свободи у політичній науці набуває актуальності та значущості, враховуючи тенденції та ризики, розкриті та проаналізовані у цій статті.

У цій статті ми базуємо наші висновки на осмисленні свободи як різновиду влади. Влади не як негативної категорії, пов'язаної з примусом. Свобода як влада - це категорії позитивна, пов'язана з необмеженою реалізацією своєї волі у суспільстві таких же людей, без шкоди для себе та оточуючих. Тому, мабуть, з цієї позиції класичний формальний підхід до соціального контролю як до природнього консенсусу, який з'явився невідомо як і невідомо звідки, має сприйматися достатньо 
критично. Сучасне суспільство - це суспільство тонкої, прозорої, але водночас жорсткої влади, яка не толерує владу дійсно вільних людей.

Проблема соціального контролю у XXI століття полягає не лише в його технологічності, насиченні суспільства інформаційними базами даних та камерами відеоспостереження та наділенні інституцій кримінальної юстиції додатковими повноваженнями контролю та нагляду. Це - лише зовнішній аспект проблематики. Внутрішній аспект пов'язаний 3 поширенням сфери проникнення соціального контролю завдяки збільшення типології та класифікації девіантів у суспільстві Постмодерну.

Щодо кордонів між тотальними інституціями, неінституційними складовими системи соціального контролю та «вільним суспільством», варто наголосити на подальшому розмиванні таких кордонів, а відтак про посилення транскарцерації суспільства та про трансформацію «влади карати» на дисциплінарно-технологічну «владу наглядати».

Проте головним висновком цього дослідження буде саме загострення проблематики добровільної відмови від свободи на користь «безпеки», або, краще сказати, поєднання «безпеки» 3 «комфортом» відповідно до вимог споживацького глобалізованого суспільства.

\section{Бібліографічний список:}

1. Ягунов Д. Глобалізаційна обумовленість «кризи покарання»: аналіз сучасних пенальних практик на основі кримінологічних поглядів Мішеля Фуко. Правова держава, 2010. 12. С.325-330.

2. Cohen S. Visions of Social Control. Crime, Punishment and Classification. Polity Press in association with BlackweU Publishers Ltd., 1985. 325 p.

3. Бауман 3. Глобализация. Последствия для человека и общества. Москва, 2004. 188 с.

4. Бек У. Что такое глобализация? Ошибки глобализма - ответы на глобализацию. Москва, 2001.

5. Свендсен Л. Філософія свободи. Львів: Видавництво Анетти Антоненко ; Київ: Ніка-Центр, 2016. 336 с.

6. Фуко М. Надзирать и наказывать. Рождение тюрьмы. Москва: Ad Marginem, 1999. 480 с.

7. Торвальд Ю. 100 лет криминалистики. URL: http://bookz.ru/authors/torval_d-urgen.html (16.07.2020).

8. Ягунов Д. «Криза реабілітаційного ідеалу» в наукових працях Роберта Мартінсона та їх значення для формування сучасної пенальної політики. Південноукраїнський правничий часопис, 2010. 4. С.28-30.

9. Ягунов Д., Севастьянова Н. «Net Widening» в системі заходів соціального контролю. Стратегія регіонального розвитку: формування та механізми реалізації. Матеріали щорічної науково-практичної конференції, 31 жовтня 2007 року. Т. 2. Одеса: ОРІДУ НАДУ при Президентові України, 2007. С. 285-288.

10. Ягунов Д. Реабілітація злочинців як мета покарання: атавізм або вимушена необхідність? Актуальні проблеми держави і права, 2011. 60. С.145-153.

11. Про внесення змін до деяких законодавчих актів України щодо посилення захисту права дитини на належне утримання шляхом вдосконалення порядку примусового стягнення заборгованості зі сплати аліментів. Відомості Верховної Ради (ВВР), 2018, № 6-7, ст.40.

12. Про запобігання та протидію домашньому насильству. Відомості Верховної Ради (ВВР), 2018, № 5, ст.35.

13. Дюркгейм Э. Социология. Ее предмет, метод, предназначение. Москва: Канон, 1995. 352 с.

14. Top 10 Countries and Cities By Number Of CCTV Cameras. URL: https://asiatimes.com/2019/12/ guess-who-has-more-cctv-cameras-per-capita (July 25, 2020).

15. Number of video surveillance cameras per thousand people in 2014 , by country.

URL: www.statista.com/statistics/484956/number-of-surveillance-cameras-per-thousand-people-by-country (July 25, 2020).

16. Surveillance camera statistics: which cities have the most CCTV cameras? URL: www.comparitech.com/ vpn-privacy/the-worlds-most-surveilled-cities (July 25, 2020).

17. Jung Y., Wheeler A. The effect of public surveillance cameras on crime clearance rates.

The University of Texas at Dallas, School of Economic, Political, and Policy Sciences.

URL: https://ideas.repec.org/p/osf/socarx/eh5bg.html (July 29, 2020).

18. Surveillance cameras and crime prevention. URL: https://www.futurelearn.com/courses/economics-ofcrime/0/steps/20272 (July 29, 2020).

19. В Telegram продают 900 ГБ персональных данных украинцев. Откуда данные и что делать? URL: https://tech.liga.net/technology/article/v-telegram-prodayut-900-gb-personalnyh-dannyh-ukraintsev-otkudadannye-i-chto-delat (12.05.2020).

20. Зростання до 70\%: карантин збільшить доходи служб доставки їжі в Україні. URL: https://rau.ua/novyni/karantyn-dostavka-edy (16.03.2020).

21. The Corrections Corporation of America, by the Numbers. URTL: www.motherjones.com/politics/2016/06/ cca-corrections-corperation-america-private-prisons-company-profile (2020, July, 12).

22. Фромм Э. Здоровое общество. - Москва, 2009. 


\section{References:}

1. Yagunov D. Hlobalizatsiina obumovlenist «kryzy pokarannia»: analiz suchasnykh penalnykh praktyk na osnovi kryminolohichnykh pohliadiv Mishelia Fuko (The globalization conditionality of the "crisis of punishment": an analysis of modern penal practices based on the criminological views of Michel Foucault). Pravova derzhava (Rule of Law), 2010. 12. S.325-330.

2. Cohen S. Visions of Social Control. Crime, Punishment and Classification. Polity Press in association with BlackweU Publishers Ltd., 1985. 325 p.

3. Bauman Z. Hlobalyzatsyia. Posledstvyia dlia cheloveka y obshchestva (Globalization. Consequences for man and society). Moskva, 2004. $188 \mathrm{~s}$.

4. Bek U. Chto takoe hlobalyzatsyia? Oshybky hlobalyzma - otvetb na hlobalyzatsyiu (What is globalization? Mistakes of globalism - answers to globalization). Moskva, 2001.

5. Svendsen L. Filosofiia svobody (Philosophy of freedom). Lviv: Vydavnytstvo Anetty Antonenko ; Kyiv: Nika-Tsentr, 2016. $336 \mathrm{~s}$.

6. Fuko M. Nadzyrat y nakazyvat. Rozhdenye tiurmy (Supervise and punish. The birth of prison). Moskva: Ad Marginem, 1999. 480 s.

7. Torvald Y. 100 let krymynalystyky (100 years of criminology). URL: http://bookz.ru/authors/ torval_d-urgen.html (16.07.2020).

8. Yagunov D. «Kryza reabilitatsiinoho idealu» v naukovykh pratsiakh Roberta Martinsona ta yikh znachennia dlia formuvannia suchasnoi penalnoi polityky ("Crisis of the rehabilitation ideal" in the scientific works of Robert Martinson and their significance for the formation of modern penalty policy). Pivdennoukrainskyi pravnychyi chasopys (South Ukrainian Law Journal), 2010. 4. S.28-30.

9. Yagunov D., Sevastianova N. «Net Widening» v systemi zakhodiv sotsialnoho kontroliu ("Net Widening" in the system of social control measures). Stratehiia rehionalnoho rozvytku: formuvannia ta mekhanizmy realizatsii (Regional development strategy: formation and implementation mechanis). Materialy shchorichnoi naukovopraktychnoi konferentsii, 31 zhovtnia 2007 roku. T. 2. Odesa: ORIDU NADU pry Prezydentovi Ukrainy, 2007. S.285-288.

10. Yagunov D. Reabilitatsiia zlochyntsiv yak meta pokarannia: atavizm abo vymushena neobkhidnist? (Rehabilitation of criminals as a goal of punishment: atavism or forced necessity?) Aktualni problemy derzhavy I prava (Current issues of state and law), 2011. 60. S.145-153.

11. Pro vnesennia zmin do deiakykh zakonodavchykh aktiv Ukrainy shchodo posylennia zakhystu prava dytyny na nalezhne utrymannia shliakhom vdoskonalennia poriadku prymusovoho stiahnennia zaborhovanosti zi splaty alimentiv (On Amendments to Certain Legislative Acts of Ukraine Concerning Strengthening the Protection of the Child's Right to Appropriate Maintenance by Improving the Procedure for Enforced Recovery of Alimony Arrears). Vidomosti Verkhovnoi Rady (VVR), 2018, № 6-7, st.40.

12. Pro zapobihannia ta protydiiu domashnomu nasylstvu (On prevention and counteraction to domestic violence). Vidomosti Verkhovnoi Rady (VVR), 2018, № 5, st.35.

13. Diurkheim Э. Sotsyolohyia. Ee predmet, metod, prednaznachenye (Sociology. Its subject, method, purpose). Moskva: Kanon, 1995. $352 \mathrm{~s}$.

14. Top 10 Countries and Cities By Number Of CCTV Cameras. URL: https://asiatimes.com/2019/12/guess-whohas-more-cctv-cameras-per-capita (July 25, 2020).

15. Number of video surveillance cameras per thousand people in 2014, by country.

URL: www.statista.com/statistics/484956/number-of-surveillance-cameras-per-thousand-people-by-country (July 25, 2020).

16. Surveillance camera statistics: which cities have the most CCTV cameras? URL: www.comparitech.com/ vpn-privacy/the-worlds-most-surveilled-cities (July 25, 2020).

17. Jung Yeondae, Wheeler Andrew. The effect of public surveillance cameras on crime clearance rates. The University of Texas at Dallas, School of Economic, Political, and Policy Sciences.

URL: https://ideas.repec.org/p/osf/socarx/eh5bg.html (July 29, 2020).

18. Surveillance cameras and crime prevention. URL: https://www.futurelearn.com/courses/economics-ofcrime/0/steps/20272 (July 29, 2020).

19. V Telegram prodaiut 900 HB personalnыkh dannыkh ukrayntsev. Otkuda dannыe y chto delat? URL: https://tech.liga.net/technology/article/v-telegram-prodayut-900-gb-personalnyh-dannyh-ukraintsev-otkudadannye-i-chto-delat (12.05.2020).

20. Zrostannia do 70\%: karantyn zbilshyt dokhody sluzhb dostavky yizhi v Ukraini (Growth to 70\%: quarantine will increase revenues of food delivery services in Ukraine). URL: https://rau.ua/novyni/karantyn-dostavka-edy (16.03.2020).

21. The Corrections Corporation of America, by the Numbers.

URTL: www.motherjones.com/politics/2016/06/cca-corrections-corperation-america-private-prisons-company-profile (2020, July, 12).

22. Fromm Э. Zdorovoe obshchestvo (Healthy society). - Moskva, 2009. 
Yagunov D. V. The Postmodern "punitive city»: concerning the issue of dispersion of social control in the XXI century

The article is focused on the problem of the essence, forms, methods and limits of social control in the Postmodern society. The article contains an analysis of the views of the most famous scientists who laid the foundations of modern understanding of social control, and the author's proposals for the application of such views in the XXI century society. The main thesis of this study is that modern social control is more insightful, subtle and comprehensive (primarily due to its greater manufacturability). Therefore, there is a real danger of losing freedom in the Postmodern society. The article emphasizes the importance for the political science of the XXI century of the works of the French philosopher Michel Foucault and the American sociologist Stanley Cohen on the essence of social control on the example of the concept of punitive city, which serves as a model of modern society of technological social control. The article contains an analysis of transformation of different models of social control with the corresponding characteristics of each model. The article analyzes the application of the categories introduced by Michel Foucault in the XXI century ("rank", "exam", "discipline") and focuses on the relevance of such categories. The article provides practical examples of "encroachment on liberty" (such as mass surveillance cameras and information databases) and the dissemination of more insightful social control in the field of criminal justice. Attention is paid to examples of the application of the concept of Net Widening in national criminal justice systems. Attention is also paid to the "crisis of the rehabilitation ideal", which occurred after the publication in 1971 of the work of the American sociologist Robert Martinson. The article concludes that freedom is a kind of power. Power is seen not as a negative category associated with coercion, but as a positive category associated with the unlimited realization of the human's will in the society, without harm to themselves and others. Therefore, from this point of view, the classical formal approach to social control as a natural consensus, which emerged from nowhere and from nowhere, should be taken critically. Modern society is a society of subtle and transparent, but at the same time rigid power, which does not tolerate the power of truly free people. The main conclusion of this study will be the aggravation of the issue of voluntary renunciation of freedom in favor of "security", or, better said, the combination of "security" with "comfort" in accordance with the requirements of a globalized consumer society.

Key words: globalization, nation state, penitentiary system, penitentiary institution, prison, social control, limits of social control, goals of criminal punishment, total institutions, "punitive city». 